\title{
Edukasi Prokes 5M dan Vaksinasi di Jemaat GPM Negeri Lama dalam Pencegahan COVID-19
}

\author{
Gress Masela, Nova Kakisina, Jonathan Soumokil, Jullia Hukubun, Theressa Kaimarehe, Maya \\ Wakim, Mersye Heumasse, Glorify Latuihamallo, Jean Supusepa, \& Rachel Iwamony*
}

Universitas Kristen Indonesia Maluku, Indonesia

\begin{abstract}
Gereja-gereja di seluruh dunia terlibat dalam upaya penghentian penyebaran virus COVID-19, termasuk Gereja Protestan Maluku (GPM). Karena itu, Jemaat GPM Negeri Lama juga memiliki peranan penting dalm hal ini. Melalui berbagai macam kesempatan, para pelayan mengajak umat untuk mengikuti anjuran pemerintah, yaitu memakai masker, rajin mencuci tangan, menjaga jarak, dan menjauhi kerumunan. Selain itu, demi meningkatkan kekebalan tubuh manusia terhadap COVID-19, pemerintah mendorong masyarakat untuk menerima vaksinasi. Namun, tidak semua orang memiliki kesadaran untuk menerima vaksinasi, termasuk sebagian warga Jemaat GPM negeri lama. Mereka yang menolak menerima vaksinasi memiliki banyak alasan. Berdasarkan analisis situasi dilapangan terdapat beberapa masalah yang ditemukan di jemaat GPM negri lama antara lain 1). Kurangnya kesadaran dan kepedulian jemaat GPM Negeri Lama mengenai prokes 5M, 2). Kurangnya kesadaran jemaat negri lama terhadap vaksinasi. Dalam pelaksanan PPM ini, ada 2 program yang akan dilakukan yakni: Program Sosialisasi dan Edukasi. Program pertama yang dilakukan ialah sosialisasi 5M, program kedua yang dilakukn ialah Edukasi mengenai vaksin. Luaran kegiatan ini telah dipublikasikan lewat youtube chanel "Gress Masela: https://youtube.com/channel/UCSnugicyugYoguHbZlDw_A"
\end{abstract}

Keywords: Jemaat GPM Negeri Lama, COVID-19, Prokes 5M, Vaksin

\section{Introduction}

Jemaat GPM Negeri Lama merupakan salah satu Jemaat di Maluku yang terpapar pandemic COVID-19. Dimana COVID-19 ini mewabah secara global, yang mengakibatkan terjadinya masalah baik dari sisi Kesehatan, Pendidikan, Ekonomi serta Social-Budaya. Virus COVID-19 ternyata sudah bermutasi dalam beberapa varian yakni, varian virus corona Inggris (B.1.1.7) disebut Alpha, varian virus corona Afrika (B.1.351) disebut Beta, varian virus corona Brasil (P.1) disebut Gamma dan varian virus carona India (B.1.617.2) disebut Delta (Aida \& Nugroh, 2021). Virus corona yang bermutasi dalam beberapa varian ini membuat semua orang terkhususnya Jemaat GPM Negeri Lama resah. Apalagi varian virus corona Delta, yang mempunyai tingkat penyebaran $10 \times$ lebih cepat ini sudah memasuki wilayah Indonesia termasuk Maluku.

Sampai sekarang ini pemerintah terus memberikan himbauan kepada masyarakat untuk tetap mematuhi protokol kesehatan dan tetap melakukannya dengan ketat bahkan sanksi-sanksi pun dipakai untuk memberikan efek jera agar upaya untuk memutus rantai penyebaran virus COVID-19 ini boleh berhasil dilaksanakan (Damara, 2021; Paath, 2020). Selain himbauan untuk melaksanakan prokes 5M dengan ketat, penanggulangan COVID-19 dengan pengadaan dan pelaksanaan vaksin juga dipakai pemerintah dengan tujuan untuk mengurangi transmisi atau penularan COVID-

\footnotetext{
* Corresponding author:

E-mail address: racheliwamony07@gmail.com
} 
19, menurunkan angka kesakitan dan kematian akibat COVID-19, mencapai kekebalan kelompok di masyarakat (herd immunity), selain itu juga melindungi masyarakat dari COVID-19 agar tetap produktif secara sosial dan ekonomi. Program Pengadaan Vaksin COVID-19 dan Pelaksanaan Vaksinasi COVID-19 pada prinsipnya merupakan bagian dari upaya Pemerintah untuk menanggulangi COVID-19 dengan tujuan untuk pembentukan herd Immunity mengurangi angka kesakitan dan angka kematian akibat COVID-19.

Tujuan tersebut dapat tercapai dengan sinergitas dan peran dari semua pihak terutama masyarakat. Sosialisasi terkait Program Pengadaan Vaksin COVID-19 dan Pelaksanaan Vaksinasi COVID-19 terus dilakukan agar masyarakat mendapat pemahaman yang tepat dan mau mengambil peran diantaranya melakukan Vaksinasi COVID-19 apabila ditetapkan sebagai penerima Vaksin COVID-19 dan menjalankan anjuran/himbauan dari Pemerintah untuk menerapkan protokol kese hatan serta pola hidup yang sehat demi kesehatan dan keamanan bersama (Dewi, 2021). Berdasarkan data yang diperoleh dari hasil observasi SATGAS Negeri Lama, ada 17 anggota jemaat yang terkonfirmasi positif COVID-19 dan diharuskan untuk melakukan isolasi baik isolasi mandiri maupun isolasi terpusat dan setelah menjalani isolasi, mereka dinyatakan sembuh dan telah menerima surat keterangan kesehatan dari puskesmas sebagai bukti mereka telah sembuh (Hukubun, personal communication, August 5, 2021).

Berkaca dari pengalaman yang terjadi membuat Jemaat GPM Negeri Lama lebih berhati-hati dalam melakukan segala aktivitas. Kebijakan-kebijakan pun diambil oleh Ketua Majelis Jemaat sebagai tindakan untuk memutus mata rantai penyebaran COVID-19 seperti menghimbau jemaat untuk menaati protokol kesehatan 5M dan juga melakukan vaksinasi. Jemaat GPM Negeri lama sangat antusias melakukan vaksinasi namun sebagian jemaat juga takut melakukan vaksinasi dikarenakan kurangnya pengetahuan tentang vaksi dan lebih terfokus pada isu-isu yang beredar (Hukubun, personal communication, August 5, 2021).

\section{Permasalahan Prioritas Mitra}

Berdasarkan hasil dari pengamatan dilapangan ditemukan 2 masalah yang paling dominan dari jemaat GPM Negeri Lama yaitu:

a. Masih kurangnya kesadaran Jemaat GPM Negeri Lama untuk mematuhi Protokol Kesehatan (5M) dalam rangka pencegahan COVID-19.

b. Masih kurangnya pengetahuan Jemaat GPM Negeri Lama tentang Vaksinasi sebagai bentuk pencegahan COVID-19

\section{Solusi Permasalahan}

Lewat masalah yang ditemukan oleh kelompok di lapangan, maka ada 2 solusi yang ditawarkan oleh kelompok dalam pencegahan COVID-19, yaitu:

a. Mahasiswa KKN bersama tim satgas, babinsa, babinkamtib, serta karang taruna desa negeri lama turun ke masing-masing RT untuk membagikan masker kepada anggota jemaat yang tidak menggunakan masker, sebagai salah satu cara untuk meningkatkan kesadaran jemaat terhadap COVID 19 agar warga mematuhi protokol kesehatan, pemasangan serta pembagian leaflet dan melakukan sosialisasi, edukasi dari salah satu anggota jemaat yang berprofesi sebagai seorang dosen kesehatan (POLTEKES) kepada jemaat tentangnya pentingnya prokes $5 \mathrm{M}$ di masa pandemic.

b. Mahasiswa KKN bersama Tim Satgas, babinsa, babinkamtib, serta karang taruna desa negeri lama melakukan sosialisasi dan edukasi oleh salah seorang dosen kesehatan (POLTEKES) tentang pentingnya vaksin serta ajakan kepada jemaat untuk mengikuti vaksinasi.

\section{Metode Pelaksanaan}

Langkah-langkah kegiatan KKN yang dilakukan ini diatur sebagai berikut:

Tahap Persiapan: 
1) Tim KKN mengadakan pertemuan dengan mitra untuk menyusun rencana kegiatan

2) Tim KKN mengadakan pertemuan dengan Tim SATGAS atas arahan Ketua Majelis Jemaat

3) Tim KKN mengadakan pertemuan dengan instrukutur melalu media zoom

4) Tim KKN mempersiapkan alat dan bahan untuk kegiatan (Masker, Leaflet, Antiseptik, makanan dan minuman untuk tenaga medis dan Tim Satgas)

Tahap Pelaksanaan:

Metode kegiatan yang dipakai adalah metode langsung, yaitu dengan turun langsung ke lapangan mendatangi rumahrumah jemaat per-RT dan beberapa titik kumpul yang sudah disiapkan.

1) Kegiatan sosialisasi dan edukasi yang didalamnya ada program untuk memberikan masker dan leaflet dilaksanakan dua kali dengan menghampiri rumah-rumah Jemaat per-RT dan beberapa titik kumpul. Tujuan kegiatan sosialisasi dan edukasi pertama dan kedua adalah meningkatkan pengetahuan dan pemahaman jemaat tentang Prokes 5M dan juga vaksin. Pada kegiatan ini akan diisi oleh pemateri dari SATGAS yang merupakan salah satu anggota jemaat yang berprofesi sebagai dosen kesehatan poltekes, tim SATGAS, tim KKN, dan jemaat sebagai mitra. Luaran dari kegiatan akan dipublikasikan pada artikel dan akun youtube "Gress Masela: https://youtube.com/channel/UCSnugicyugYoguHbZlDw_A"

2) Kegiatan sosialisasi dan edukasi pertama dan kedua dengan tujuan meningkatkan pengetahuan dan pemahaman jemaat tentang Prokes 5M dan Vaksin dilakukan dalam waktu yang berbeda, dikarenakan Jemaat Negri Lama memiliki 9 RT dan karena masih dilaksanakannya PPKM maka adanya pembatasan waktu dalam memberikan sosialisasi dalam satu hari. Tahap pertama dilakukan pada 1-4 RT dan tahap kedua dilakukan pada 5-9 RT. Bersamaan dengan proses sosisalisasi dan edukasi ada juga pembagian masker kepada anggota jemaat yang tidak memakai masker baik yang mengikuti sosialisasi maupun yang tidak mengikuti.

\section{Hasil dan Luaran yang Dicapai}

Berdasarkan kesepakatan kelompok dengan mitra maka peserta adalah jemaat negri lama maka dari itu diadakannya pertemuan antara kelompok dengan mitra. Dari rencara kerja pelaksanaan yang telah dibuat dan disepakati dalam rapat kelompok berasama mitra, maka kegiatan terbagi dalam beberapa tahapan pelaksanaan sebagai berikut:

1) Pelaksanaan Sosialisasi tetang Prokes $5 \mathrm{M}$ dan Vaksinasi

Pada tahapan pelaksanaa kegiatan sosialisasi ini, jemaat dipandu oleh tim SATGAS dan kelompok untuk lebih memahami tentang pentingnya prokes $5 \mathrm{M}$ dan Vaksinasi bagi kehidupan bersama. Seperti; penggunaan masker ganda dengan kombinasi masker medis + masker kain, mencuci tangan dengan menggunakan air mengalir dengan sabun atau menggunakan hand sanitizer, menjaga jarak minimal 1 meter, menjahui kerumunan, mengurangi mobilitas, sebisa mungkin semua kegiatan dilakukan dari rumah.

Kegiatan hari pertama berlangsung selama 5 jam tatap muka, yaitu sejak pukul 12:00 - 17:00 WIT. Dalam proses sosialisasi ini menggunakan metode ceramah dan Tanya jawab namun realita dalam pelaksanannya tidak banyak yang mengajukan pertanyaaan. Dan didalamnya juga tim satgas dan kelompok membagikan leaflet dan masker bagi jemaat yang terlibat dalam kegiatan sosialisasi dan jemaat yang tidak menggunakan masker. 


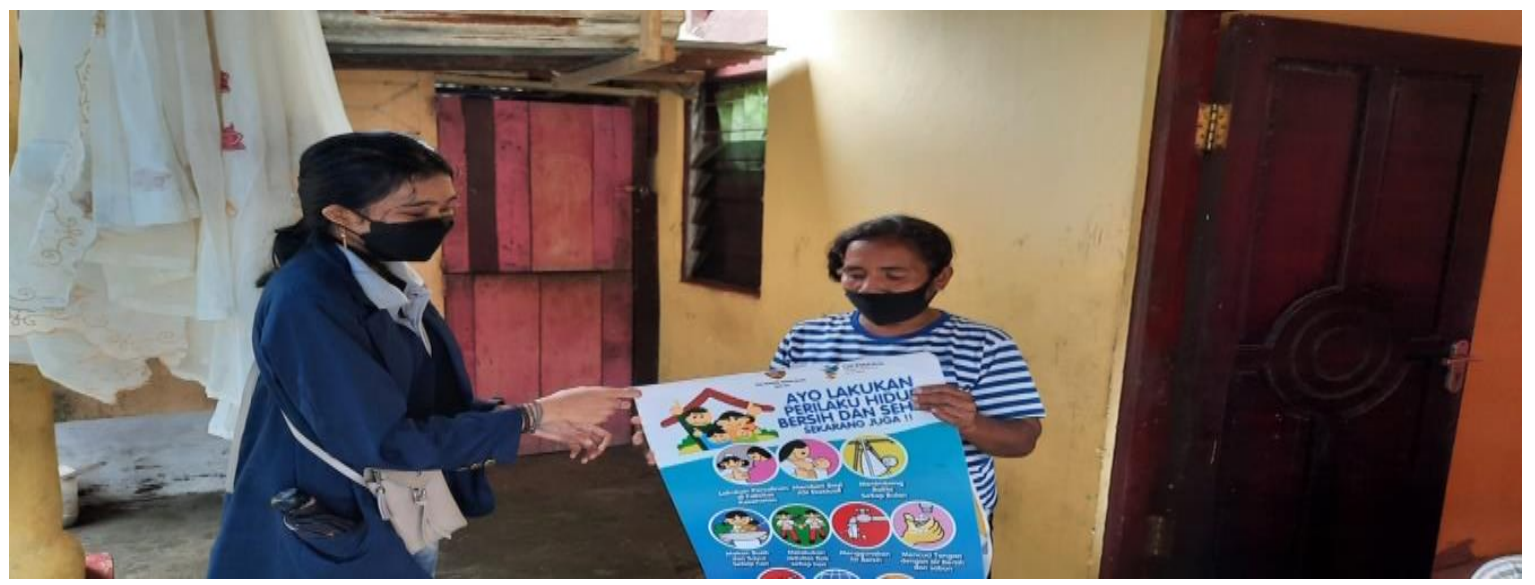

Gambar 1. Pembagian Leaflet di rumah-rumah Jemaat pada saat Sosialisasi dan Edukasi oleh Mahasiswa KKN

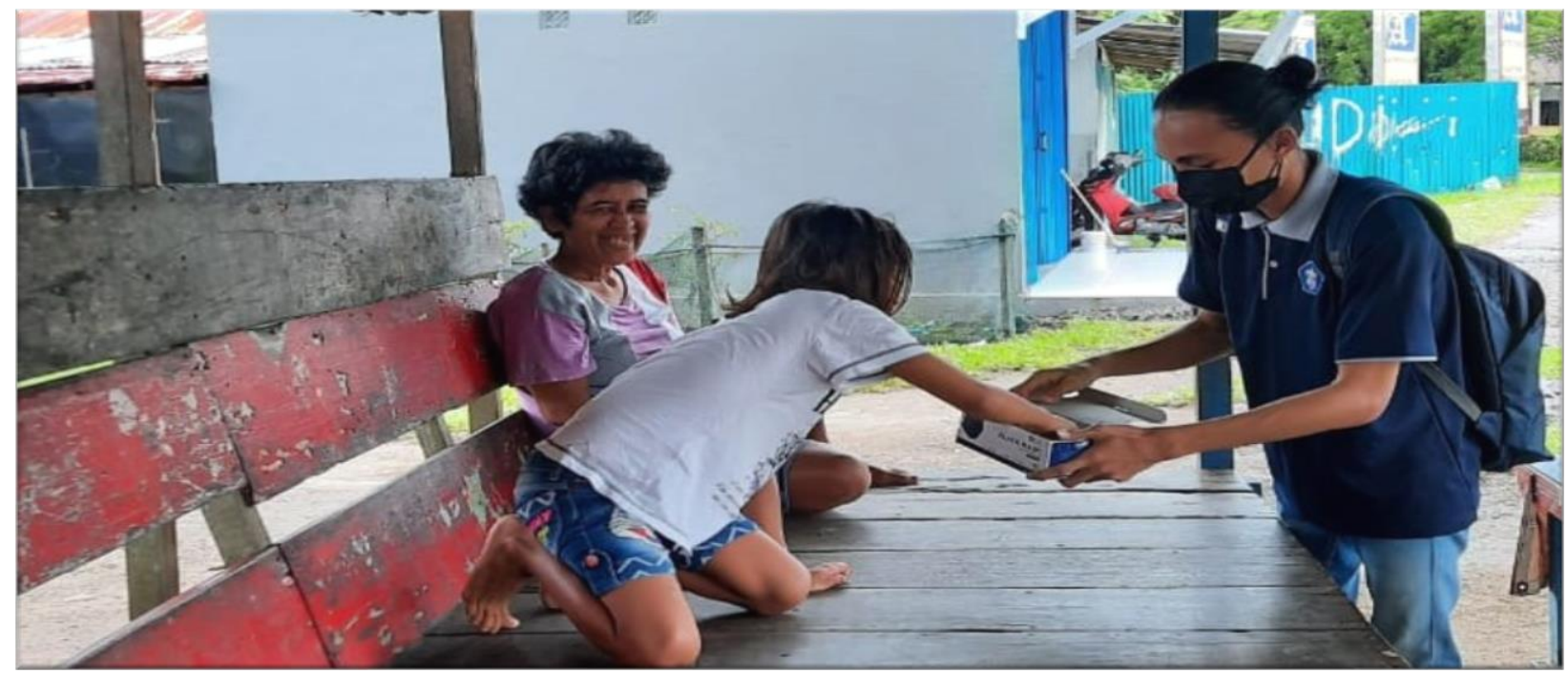

Gambar 2. Pembagian Masker bagi Jemaat yang tidak memakai masker pada saat sosialisasi dan edukasi setia RT oleh Mahasiswa KKN

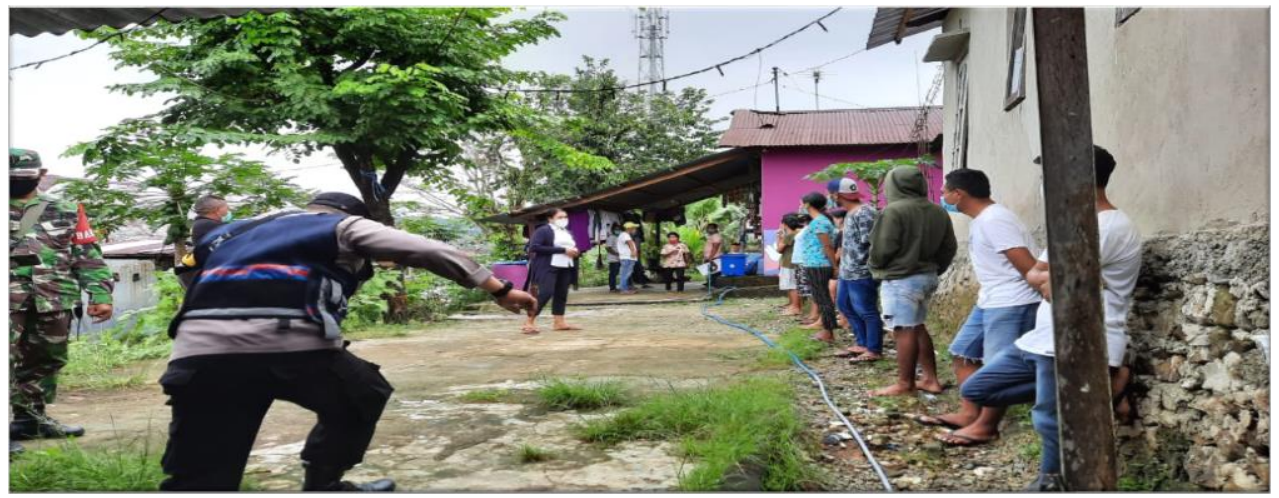

Gambar 3. Sosialisasi Edukasi Pertama di setiap RT oleh SATGAS Negeri Lama, dosen kesehatan (POLTEKES) dan Masiswa KKN 


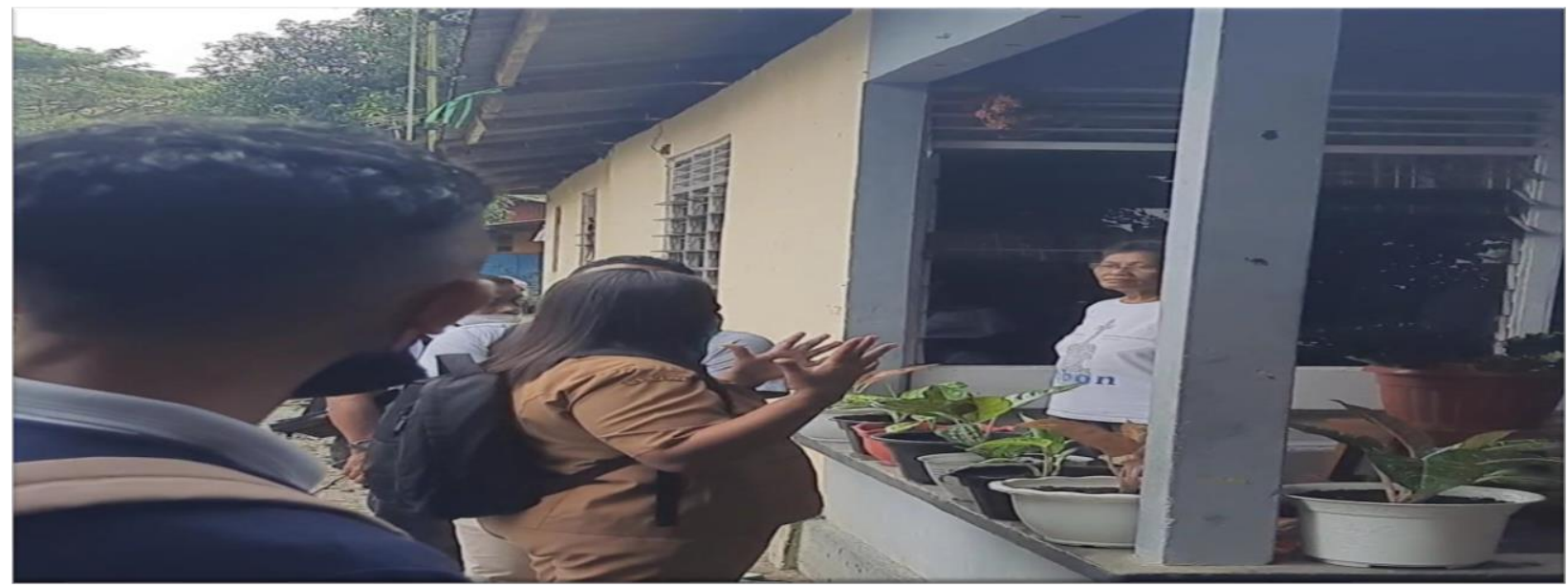

Gambar 4. Sosialisasi edukasi kedua di rumah-rumah warga oleh Tim SATGAS Negeri Lama dan Mahasiswa KKN

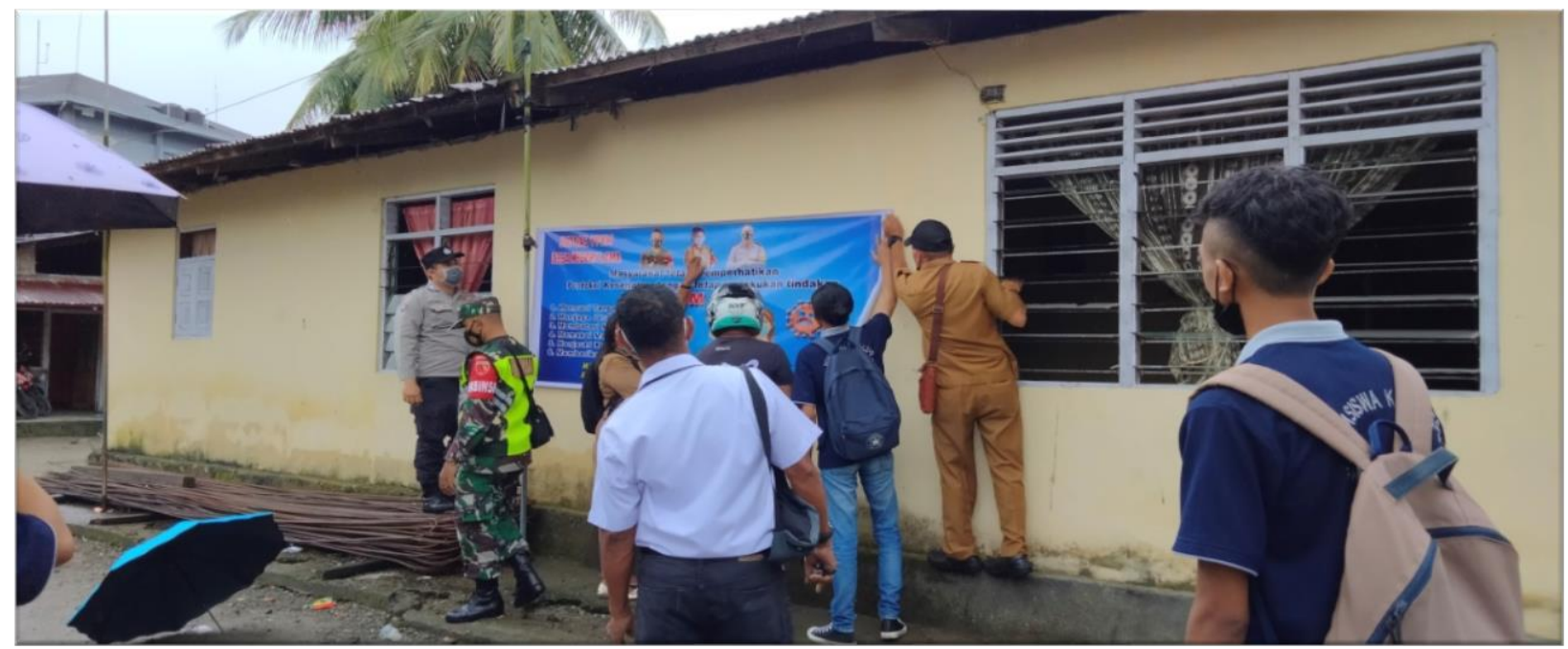

Gambar 5. Pemasangan Spanduk tentang 5M dan Vaksinasi di setiap RT oleh Tim SATGAS dan Mahasiswa KKN

2) Partisipasi kelompok dalam vaksinasi dengan mitra (Tim Satgas)

Pada tahapan ini, kelompok diikut sertakan didalam kegiatan vaksinasi yang diselenggarakan oleh tim satgas Negeri Lama, dalam hal ini kelompok memfasilitasi kegiatan tersebut seperti : tanggung jawab Konsumsi, masker dan hand sanitizer. Kegiatan vaksinasi dilaksanakan sebanyak 2x kegiatan pertama vaksin berlagsung pada 17 Juli 2021 Pukul 09:50 - 19:20 WIT . dan pada kegiatan kedua vaksin dilaksanakan pada 14 Agustus 2021 Pukul 10:00 - 17:10 WIT. Dalam kegiatan ini dilaksanakan dua tahap vaksinasi baik vaksinasi tahap pertama maupun vaksinasi tahap kedua. 


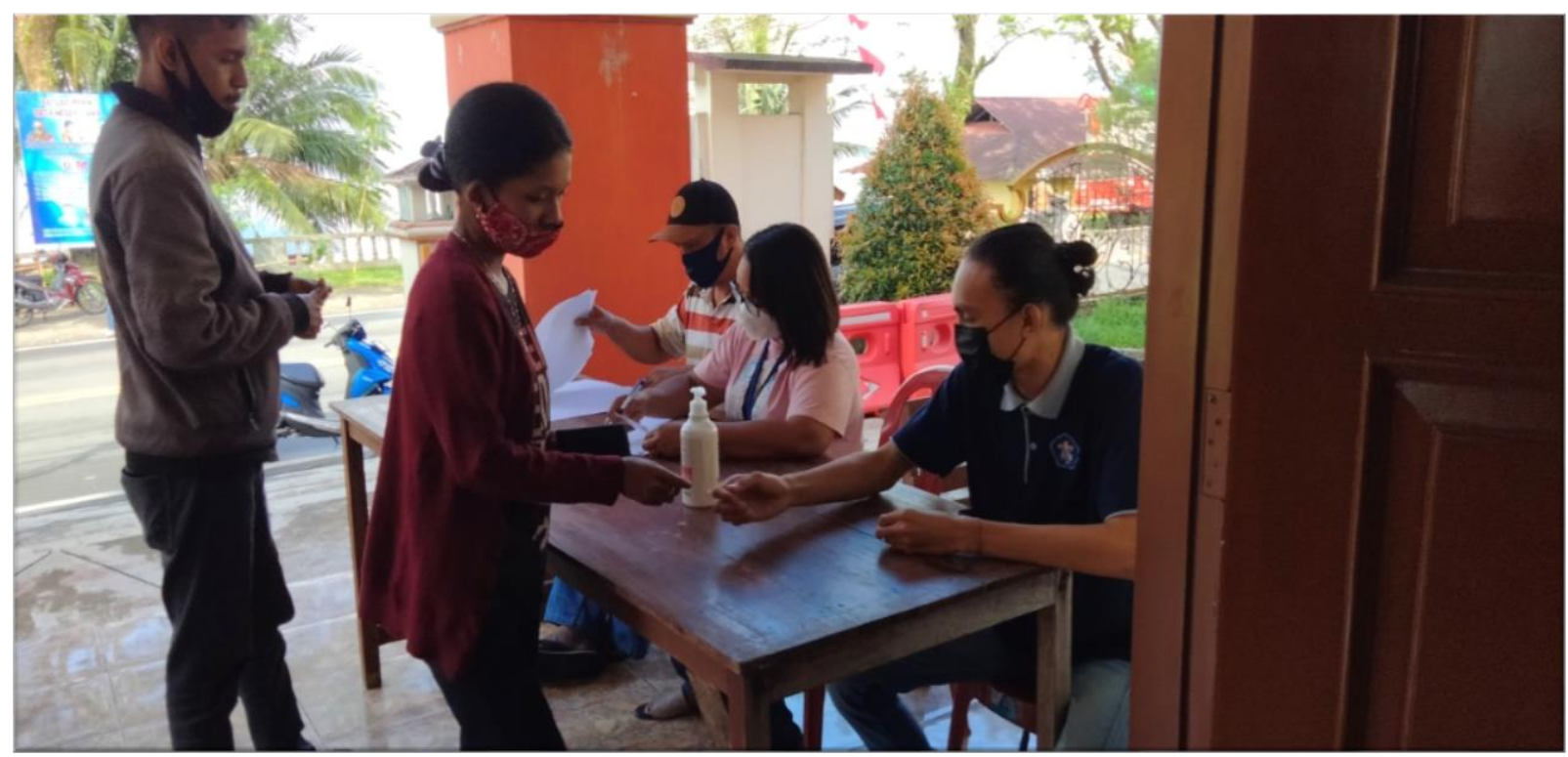

Gambar 6. Sebelum Vaksin setiap orang harus mendaftarkan diri dan mengambil nomor antrian baik itu Vaksin pertama maupun kedua

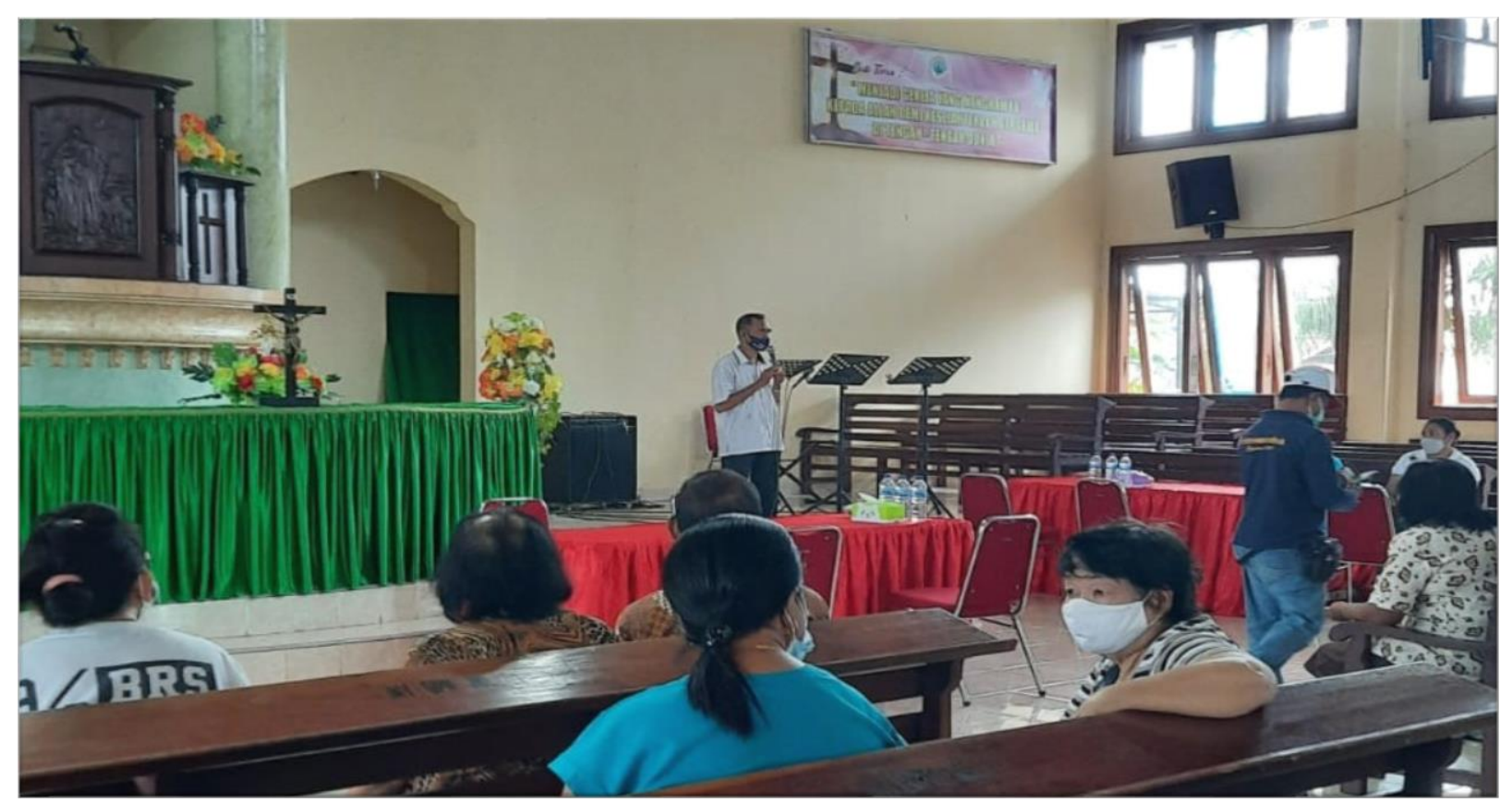

Gambar 7. Arahan oleh KMJ dan doa bersama setiap sebelum Vaksin Pertama dan kedua Jemaat GPM Negeri lama. 


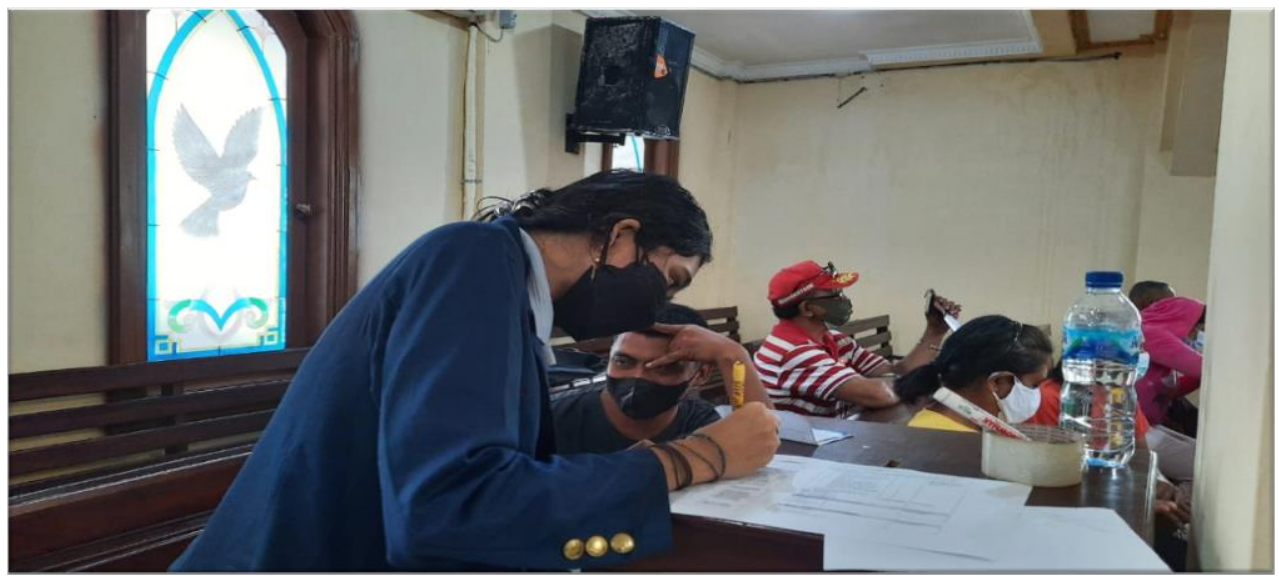

Gambar 8. Mahasiswa membantu orang tua yang sudah lanjut usia untuk mengisi biodata Vaksin baik itu vaksin pertama maupun vaksin kedua

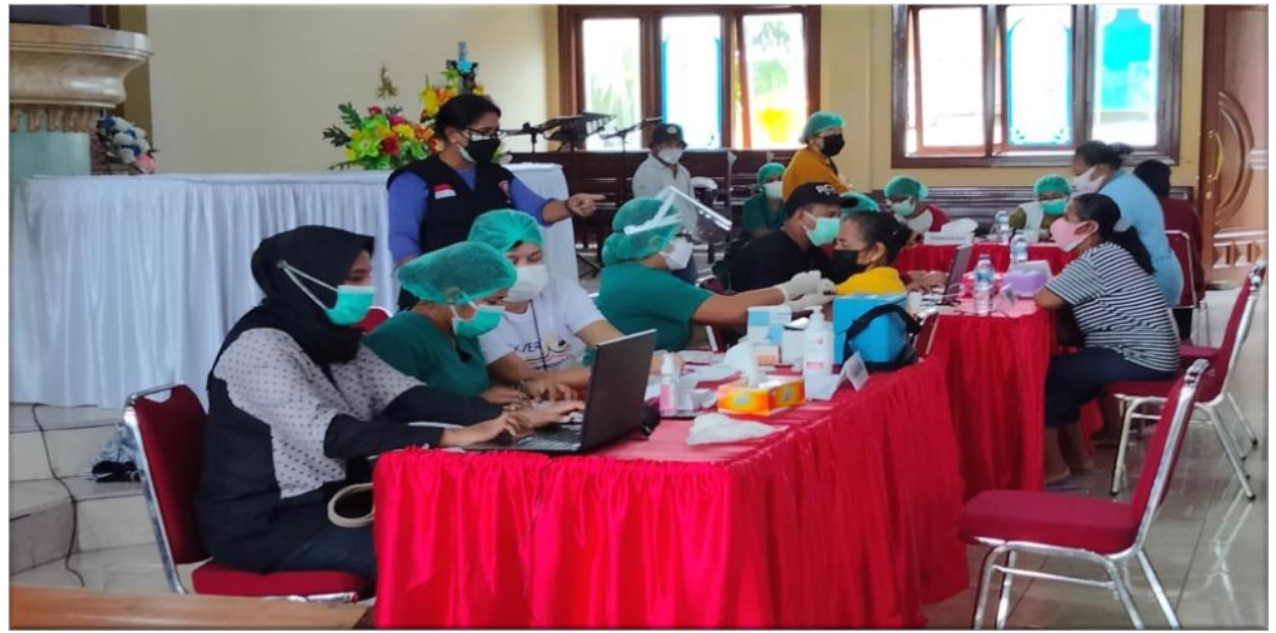

Gambar 9. Proses Vaksinasi oleh Tenaga Medis (Vaksin Pertama)

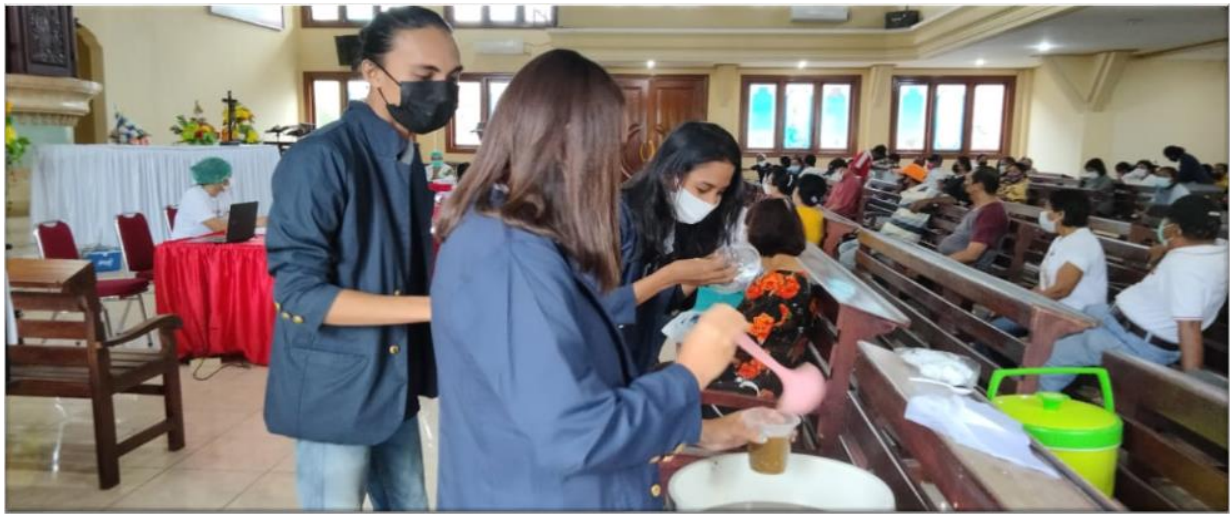

Gambar 10. Proses penyiapan konsumsi yang akan dibagikan kepada setiap jemaat yang baru selesai Vaksin (dilakukan setiap Vaksin pertama dan kedua) 


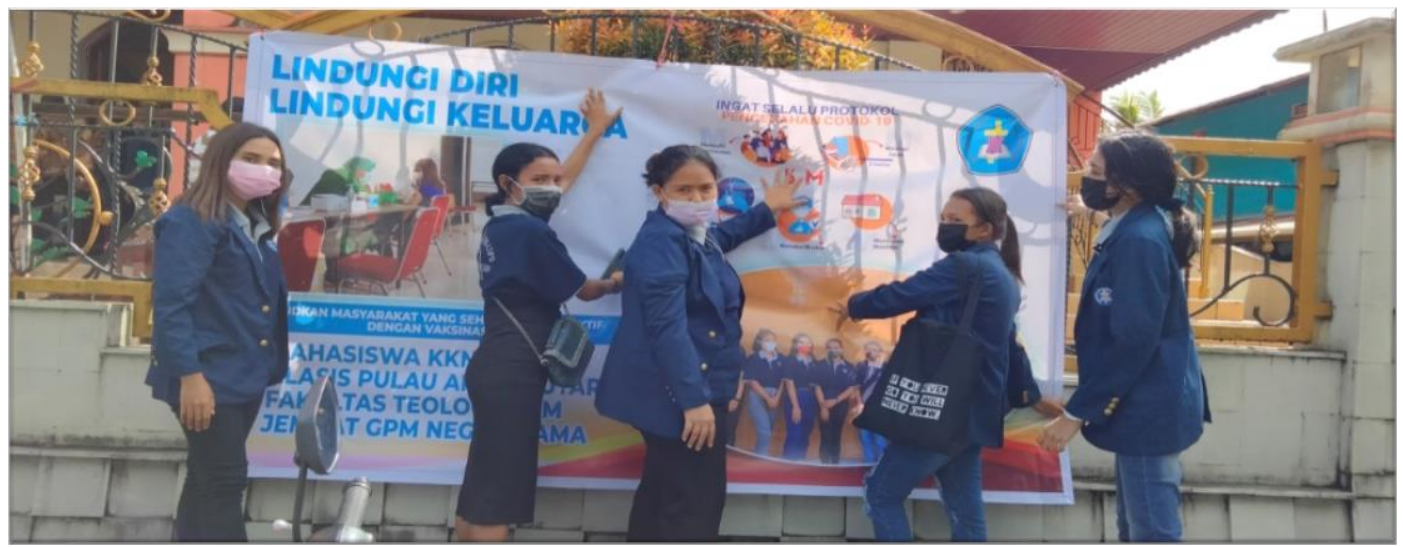

Gambar 11. Pemasangan Spanduk tentang Protokol Keshatan dan Vaksinasi oleh Mahasiswa KKN di depan Gereja pada Vaksin kedua Jemaat GPM Negeri lama

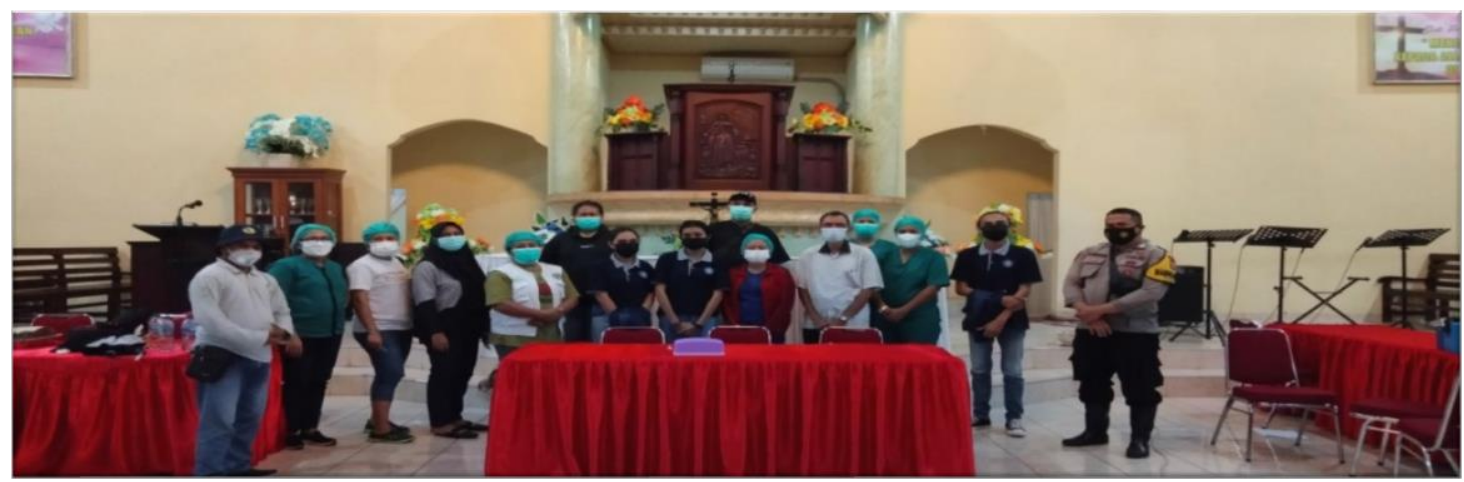

Gambar 12. Foto bersama antara Ketua Majelis Jemaat, tim satgas, tenaga medis, Babinkamtibnas dan mahsiswa KKN setelah selesai Vaksin pertama

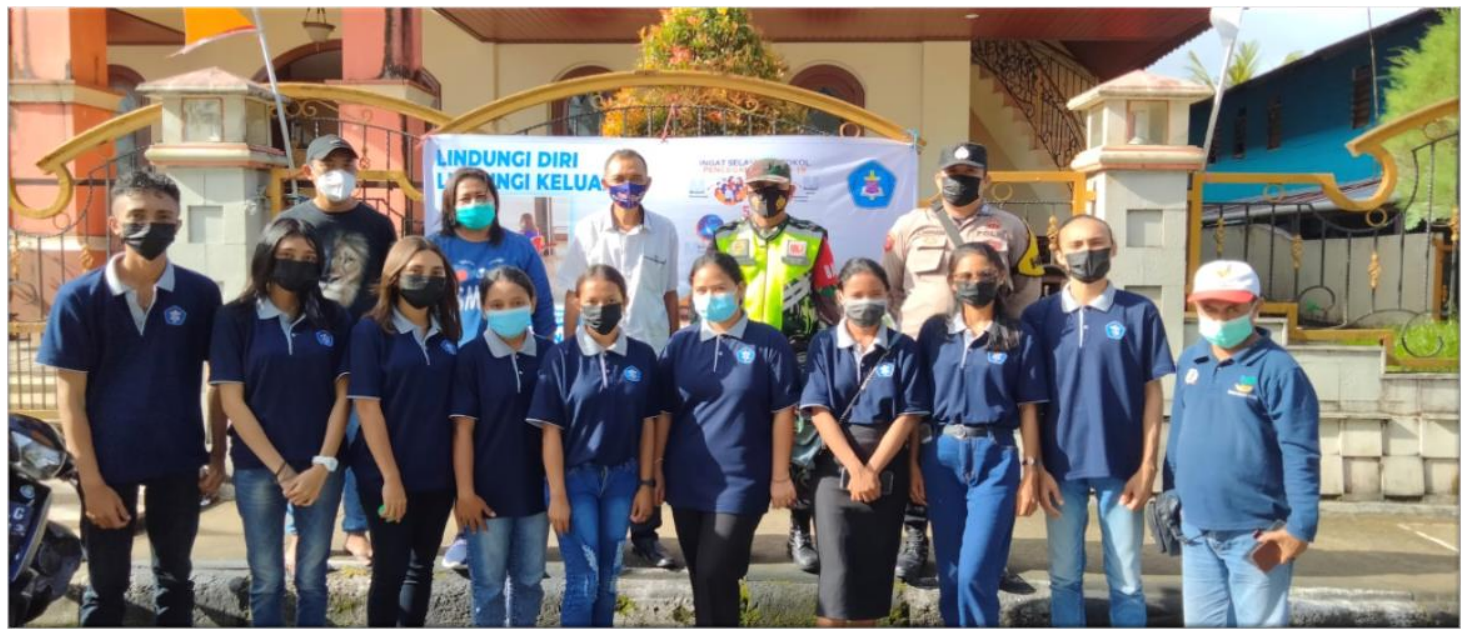

Gambar 13. Foto bersama antara Ketua Majelis Jemaat, tim satgas, Babinsa, Babinkamtibnas dan mahsiswa KKN setelah selesai Vaksin Kedua 


\section{Kesimpulan}

Demikian kegiatan pengabdian kepada Jemaat Negeri Lama yang dapat dilaksanakan oleh Mahasiswa KKN Klasis Pulau Ambon Utara (UKIM), sebagai luaran kegiatan ini, Kelompok telah menerbitkan video tentang segala kegiatan yang telah telaksaakan pada media elektronik yaitu youtube "Gress Masela: https://youtube.com/channel/UCSnugicyugYoguHbZIDw_A". diharapkan dengan adanya kegiatan pengabdian kepada jemaat yang dilaksnakan ini mampu mengajak masyarakat khususnya Jemaat Negeri Lama untuk lebih sadar akan pentingnya protokol kesehatan 5M dan Vaksinasi .

\section{References}

Aida, N. R. \& Nugroh, R. S. (2021), Inilah 10 Varian baru Virus Corona hasil mutasi, kenali gejala dan cara mencegahnya, KONTAN.CO.ID-Jakarta, 10 June 2021. Access: 19 August 2021. url: https://kesehatan.kontan.co.id/news/inilah-10-varian-baru-virus-corona-hasil-mutasi-kenali-gejala-dan-caramencegahnya?page=all

Damara, D. (2021). Imbauan tetap patuhi prokes wujud kepedulian pemerintah kepada masyarakat, BORNEONEWS, Palangka Raya, 04 Febuary 2021. Access: 19 August 2021. url: https://www.borneonews.co.id/berita/203618imbauan-tetap-patuhi-prokes-wujud-kepedulian-pemerintah-kepada-masyarakat

Dewi, A. (2021). Penanggulangan Pandemi COVID-19 Melalui Program Pengadaan Vaksin Dan Pelaksanaan Vaksin COVID19, DJA, 22 May, Access: 19 Agustus 2021. url: https://anggaran.kemenkeu.go.id/in/post/penanggulangan-pandemi-COVID-19-melalui-program-pengadaanvaksin-dan-pelaksanaan-vaksinasi-COVID-19

Hukubun, J. (2021). “COVID-19”. Hasil Wawancara Pribadi: 5 August 2021, SATGAS COVID-19 Desa Negeri Lama.

Paath, C. K. Y. (2020). Masyarat Diminta Patuh dan Ikuti Protokol Kesehatan Pemerintah, Jakarta, Beritasatu.com, 22 March 2020. Access: 19 August 2021. url: https://www.beritasatu.com/nasional/611675/masyarakat-dimintapatuh-dan-ikuti-protokol-kesehatan-pemerintah 